\title{
Chapter 2 \\ Scenario Storyline in Context \\ of Decarbonization Pathways \\ for a Future European Energy System
}

\author{
Andrea Herbst, Steffi Schreiber, Witold-Roger Poganietz, Angelo Martino, \\ and Dominik Möst
}

\begin{abstract}
This chapter presents a qualitative description of the scenario storylines for the REFLEX project. The scenario descriptions provide the overall qualitative framework for the modeling activities by setting-up two holistic socio-technical scenarios based on different storylines: the moderate renewable scenario (Mod-RES) as reference scenario and the (de-)centralized high renewable scenarios (High-RES) as ambitious policy scenarios. The chapter highlights the definition of main technoeconomic framework parameters, macro-economic and societal drivers as well as of the considered political environment.
\end{abstract}

\subsection{Introduction}

Energy systems could be seen as socio-technical systems, i.e., technical change and societal dynamics influence each other. Due to the relevance of societal dynamic values and behavioral patterns, the degree of acceptance and willingness to support technical changes as well as social policies and regulation are equally important for the success of a transformation process, compared to technological or economic

The content of this chapter is based on the REFLEX project reports from Herbst et al. (2016), Fuss et al. (2018), Zöphel et al. (2019) as well as on the REFLEX policy brief from Poganietz et al. (2017).

\footnotetext{
A. Herbst $(\bowtie)$

Competence Center Energy Technology and Energy Systems, Fraunhofer Institute for Systems and Innovation Research ISI, Karlsruhe, Germany

e-mail: Andrea.Herbst@isi.fraunhofer.de

S. Schreiber · D. Möst

Chair of Energy Economics, Technische Universität Dresden, Dresden, Germany

W.-R. Poganietz

Institute for Technology Assessment and Systems Analysis, Karlsruhe Institute of Technology,

Karlsruhe, Germany
}

\author{
A. Martino \\ TRT Trasporti e Territorio, Milan, Italy
}


factors (Verbong and Loorbach 2012). Thus, the future design of the European energy system, and by this the most suitable mix of decarbonization technologies and flexibility options, is highly dependent on interdependencies between economic constraints, technology and resource availability, and societal preferences and demands that can change over time. The interrelationships can vary between the member states, increasing the complexity for any widely accepted solution regarding the design of the European energy system. To deal with the complexity and the uncertainties of the transformation process, scenarios are a proven tool to structure and trigger discussions. The aim of the REFLEX scenario definition is to sketch the relevance of the future energy system design for the significance of different flexibility options. To clarify the options, two framework scenarios will be presented which account for socio-economic and socio-political uncertainties.

The structure of this chapter continues with the overall scenario definition and its general drivers in Sect. 2.2. The socio-technical scenario description follows in Sect. 2.3, before a detailed definition of the reference scenario Mod-RES in Sect. 2.4 is provided. Followed by the description of the applied scenario frameworks and policy measures for the ambitious High-RES centralized and decentralized scenario in Sect. 2.5. In Sect. 2.6 concluding remarks are drawn.

\subsection{Scenario Definition and General Drivers}

The European Green Deal presented by the European Commission in December 2019 has the aim of making Europe the first climate-neutral continent with no net greenhouse gas emissions by 2050 (EC 2020). Furthermore, the European greenhouse gas emission reduction targets for 2030 are increased to at least 50-55\% compared to the levels of 1990. Currently, the achievement of these 'new' European climate targets are unclear due to the economic and financial crises resulting from the uncertainties of the Covid-19 pandemic. The ambitious scenarios of the REFLEX project show a path between the achievement of the current climate targets and a reference development without additional ambitions (cf. Chapter 1). In the REFLEX project two main scenarios are distinguished: a reference scenario based on observed trends and a policy scenario representing two more ambitious decarbonization pathways for Europe until 2050. The reference scenario is defined as a moderate renewable scenario (Mod-RES) while the ambitious policy scenario can be differentiated between the decentralized versus the centralized high renewable scenario (High-RES). The following Fig. 2.1 illustrates how the REFLEX scenarios can be schematically classified in terms of the existing energy system.

Overall differences occur between the Mod-RES and High-RES scenarios, both at European and country level. The main qualitative definitions of framework conditions and policy targets for the REFLEX scenarios are shown in Fig. 2.2. In both REFLEX scenarios identical GDP and population projections have been chosen as calculation basis to ensure an undistorted analysis of technology impacts, policy options, their interaction and optimal portfolio as well as their impact on environment and society. 


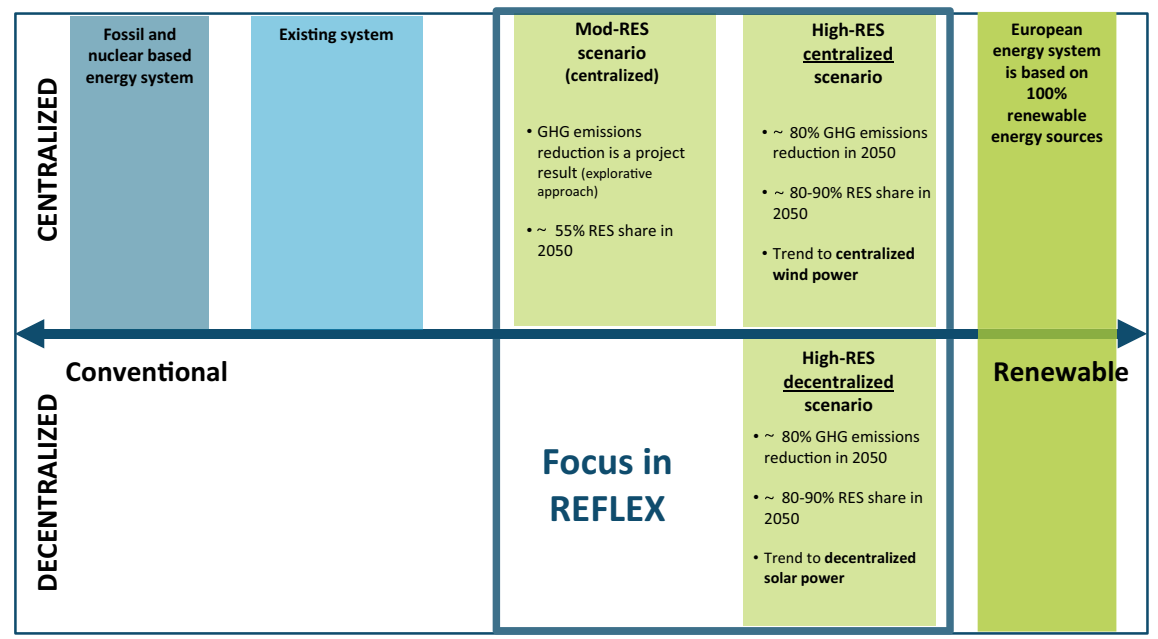

Fig. 2.1 REFLEX scenarios (transition pathways) embedded in a schematic illustration of possible energy systems. The assumed future RES share of the High-RES scenarios should provide $80-90 \%$ of today's electricity demand in Europe ( 3,000 TWh). Figure according to REFLEX project 2019

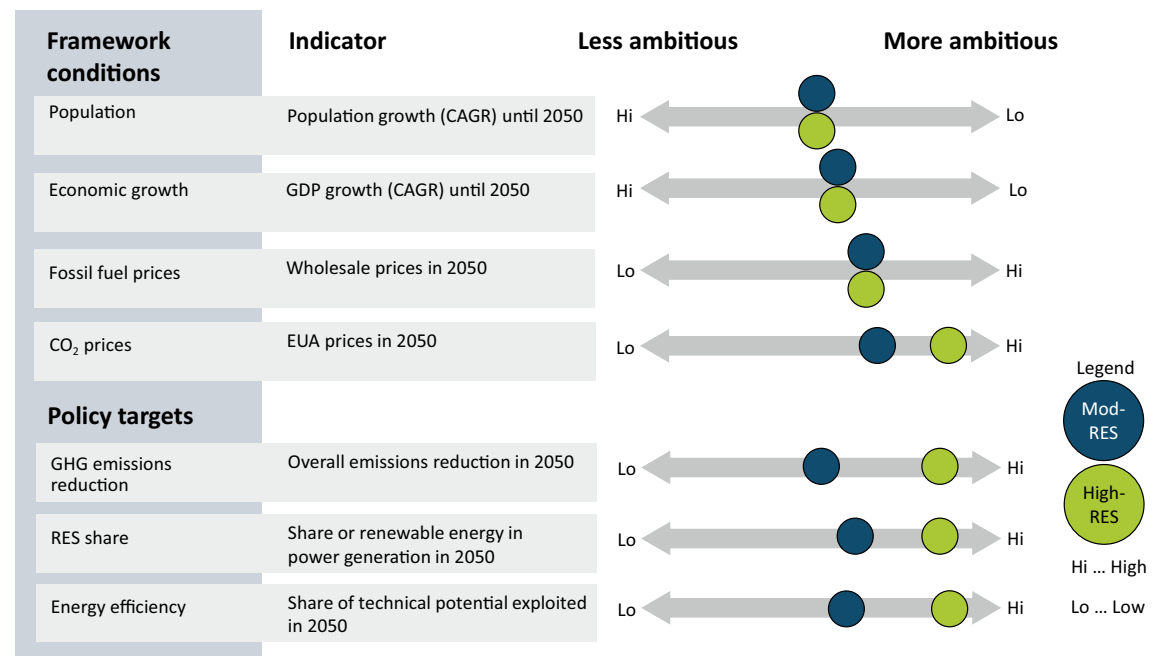

Fig. 2.2 Definition of REFLEX framework conditions Mod-RES compared to High-RES scenarios $(\mathrm{Hi}=$ High, Lo $=$ Low $)$. Figure according to REFLEX project 2019

The framework conditions for the moderate renewable scenario (Mod-RES) are based on the EU Reference Scenario 2016 (Capros et al. 2016). The Mod-RES scenario is defined to reflect the development of the energy system taking into account 
past dynamics but also the future developments regarding current economic developments and energy policies. ${ }^{1}$ Present policy targets and actions which have been already decided or implemented are reflected in Mod-RES. This is not necessarily the most likely or the most probable future development, but rather serves as a projection to which the policy scenario with ambitious decarbonization pathways is compared to (cf. Figure 2.2).

The framework conditions for the high renewable scenario (High-RES) are similar to those of Mod-RES in terms of population and economic growth, while energy prices and $\mathrm{CO}_{2}$ prices are assumed to be higher. Furthermore, ambitious climate policies are considered in High-RES. One major target of the scenario is to limit global temperature increase to $2^{\circ} \mathrm{C}$, by more drastically reducing $\mathrm{GHG}$ emissions and achieving the EU 2020 energy saving targets in the short term. Higher contribution from learning curves and need for flexibility options due to a large share of intermittent renewable energy sources occur. To capture the different possible stances on a future energy system without differentiating too much, two versions of the high renewable scenario (High-RES) are developed within REFLEX: the decentralized case and the centralized case. Major differences of these two cases concern the amount of (de-)centralized technologies. This includes both the demand and supply side in the sectors electricity, heat, and transport. A more detailed distinction follows in Sect. 2.5.

The assumptions regarding general scenario drivers are based on the EU Reference Scenario 2016 provided by the European Commission (Capros et al. 2016) and integrated into the overall REFLEX modeling platform. Common assumptions that are the same for the reference (Mod-RES) and policy (High-RES) scenarios include among others the gross domestic products (GDP), gross value added, number of households, wholesale prices for major energy carriers and population. Assumptions that differ between the scenarios are for instance GHG emission reduction targets, RES shares, energy efficiency measures, vehicle stocks, fuel taxes or $\mathrm{CO}_{2}$ emission allowance prices, to name few. More information about the scenario-specific assumptions are included in Herbst et al. 2016 and Fuss et al. 2018.

\subsection{Socio-Technical Scenario Framework}

The aim of the socio-technical scenario descriptions is to provide a qualitative account of the potential future social, economic, political, and technological drivers that are coherent with the REFLEX quantitative scenarios. The scenario descriptions are based on previous work that developed future scenarios (e.g., Watson and Albritton 2001; Bernstein et al. 2008; UNEP 2012; van Vuuren et al. 2012; Pachauri et al. 2014). The REFLEX socio-technical scenarios use the Global Environmental Outlook 4 (GEO-4) scenarios as a starting point. The reasons therefore is that the GEO-4 scenarios were developed in consultation with governments and other organizations

\footnotetext{
${ }^{1}$ Cut-off date is the end of 2015 .
} 
across the world. Furthermore, the GEO-4 scenarios reflect differences in key drivers that the REFLEX scenarios also aim to reflect. More specific descriptions are shown in the following Table 2.1.

The primary assumption of the Mod-RES scenario is that no policy measures are introduced beyond those that have been decided or already implemented (cut-off date 2015). Therefore the Mod-RES scenario emphasizes the continuation of existing policies on climate change mitigation, innovation, value systems, and economic growth. In particular, the Mod-RES scenario assumes that the current balance between the government and private sector is maintained in the future, and free trade remains a prime goal of international cooperation. The maintenance of the status quo is evidenced in the continued role of private institutions in education, healthcare, and research and development aid. Meanwhile, as a reference scenario, only existing international agreements and policies are in place to mitigate environmental degradation and climate change. Since no new policy measures are assumed, there is a little emphasis in this scenario on social development beyond the status quo either. Public participation in government is relatively low, governmental North-South development assistance is unchanged and no further action is taken to develop cultural understanding and diversity. Markets are open to international trade, and there is little regulation to ensure just employment conditions. Personal values are individually focused and individual resource demands follow historical trends related to economic output. The socio-technical context of Mod-RES is based on the assumptions of the 'Market First' scenario in GEO-4 (UNEP 2007).

The High-RES scenario assumes a strong policy commitment to achieve societal goals for climate change mitigation, as well as other social and economic goals. In this scenario global governments become sufficiently aware of the myriad social and environmental challenges facing society to implement policy to yield improvements in these areas. Economic growth is maintained at the same level as in the reference scenario (Mod-RES). However, in the High-RES scenario economic growth is always considered simultaneously with environmental and social impacts. Thus this scenario differs from Mod-RES, in terms of increased role for government in general and cooperation on environmental and social issues. Further, in the High-RES scenario there is increased public spending worldwide on health and education, and growing North-South development aid. In light of this cooperation, international institutions such as the EU and UN increase in importance and new cooperation emerge. Technological innovation still has a strong market focus, though there is a larger role for government engagement. Innovations focus as much on reduction of environmental impact as on economic efficiency. Trade between nations is encouraged, but requirements for fair trade are emphasized. Considering societal values, there is little overt action on the issue of cultural understanding and diversity. However, public participation in governance is generally higher in the High-RES scenario compared to the Mod-RES scenario. Personal values are in general more community-inclined than in Mod-RES scenario, though individual resource demands still follow historical trends related to economic output. The socio-technical context of High-RES is based on the assumptions of the 'Policy First' scenario in GEO-4 (UNEP 2007). 


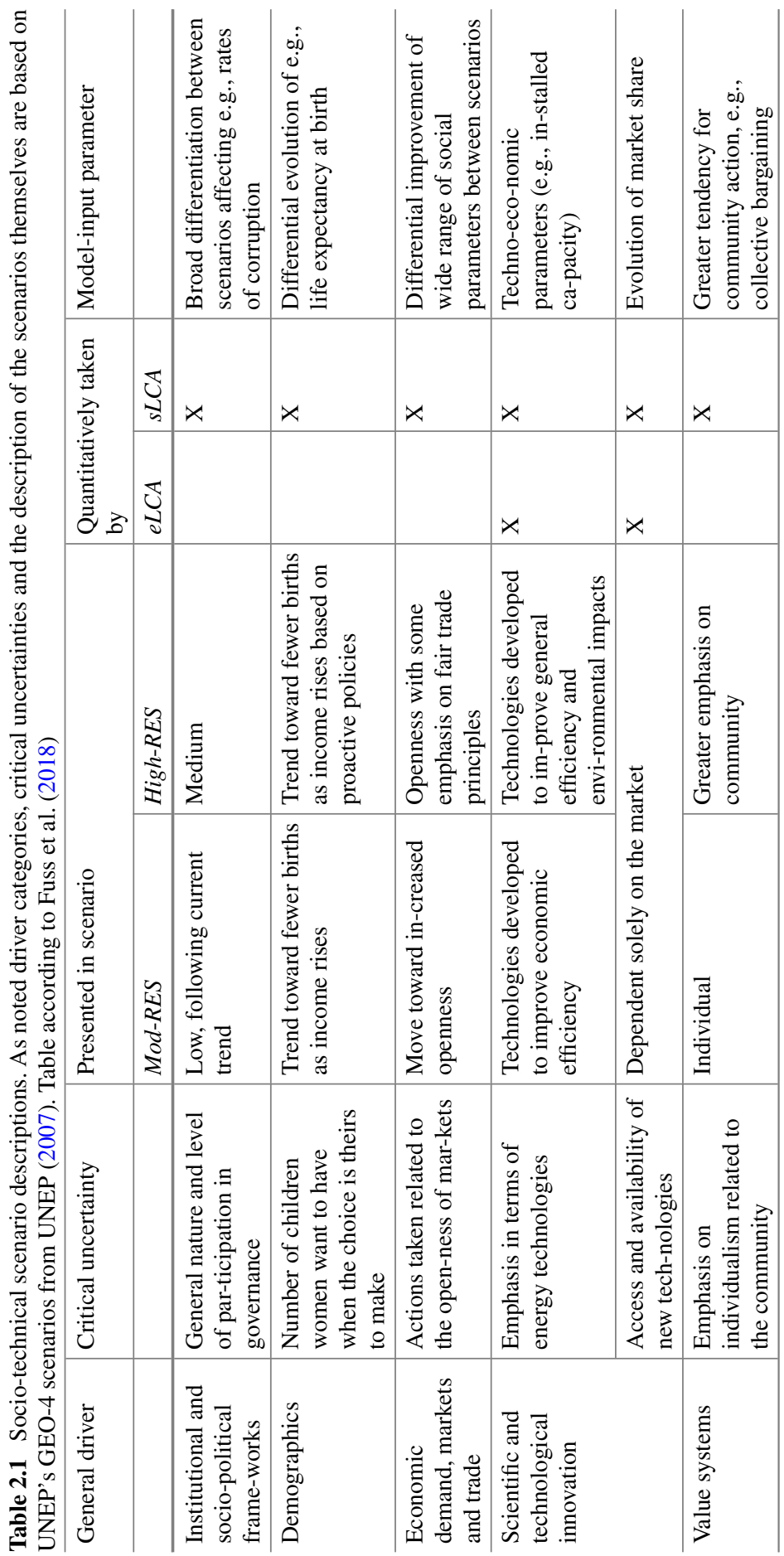




\subsection{Moderate Renewable Energy Source Scenario (Mod-RES)}

The moderate renewable scenario (Mod-RES) considers targets and actions which have been decided or are already implemented at European and national level in 2015. Selected relevant policies in this context are:

- the Renewable Energy Directive (Directive 2009/28/EG; CEU 2008)

- the Energy Efficiency Directive (Directive 2012/27/EU)

- the Directive on Energy Performance of Buildings (Directive 2010/31/EU)

- the Ecodesign Directive (Directive 2009/125/EC)

- the Directive on the Promotion of Clean and Energy Efficient Road Transport Vehicles (Directive 2009/30/EC)

- the EU regulation on $\mathrm{CO}_{2}$ emission from new cars and vans (Regulation (EU) No 333/2014, Regulation (EU) No 253/2014)

In addition, the EU Emissions Trading Scheme and the expected $\mathrm{CO}_{2}$ emission allowance price trajectory are relevant for industry and the power sector (based on Capros et al. 2016 for the Mod-RES scenario). Furthermore, business-as-usual technological learning is assumed in the Mod-RES scenario. However, progress from learning effects as well as knowledge transfer is less pronounced than in the HighRES scenario. In Table 2.2 the development of current policies in the Mod-RES scenario are described more in detail.

\subsection{Centralized versus Decentralized High Renewable Scenario (High-RES)}

In the high renewable scenario (High-RES) an overall $80 \%$ GHG emissions reduction in 2050 (compared to 1990) is intended, following the 'Roadmap for moving to a competitive low-carbon economy in 2050' of the European Commission (COM 2011/0112). In comparison to the existing Roadmap to a low-carbon economy in COM (2011/0112), the High-RES scenario has a special focus on the influence and potential of flexibility mechanisms and learning curve effects of specific technologies (from economies of scale but also from additional investment in R\&D and new technologies) in all sectors (e.g., electrolysis in industry or electric vehicle deployment targets in the transport sector). In addition, methanation, water electrolysis for hydrogen production, methanol synthesis, Fischer-Tropsch-synthesis, etc. could be relevant for sector coupling in this context. However, the final composition of flexibility options and additional learning curve effects is identified within the project and is, therefore, more a project result than a scenario assumption.

For the more ambitious High-RES policy scenarios, some measures from the ModRES scenario are further intensified and complemented by additional regulations and instruments in order to achieve a stronger shift to more efficient and/or innovative 
Table 2.2 Development of current policies ${ }^{\mathrm{a}}$ in the Mod-RES scenario. Based on the before mentioned legislative directives and on own assumptions. Table according to Herbst et al. (2016)

\begin{tabular}{|c|c|c|c|}
\hline $\mathrm{N}^{\circ}$ & Measures/Regulations & Legislative & Implementation \\
\hline 1 & Technology standards & Ecodesign Directive & $\begin{array}{l}\text { MEPS for all lots for which } \\
\text { regulations have been } \\
\text { implemented before } 29 \\
\text { February } 2016\end{array}$ \\
\hline 2 & $\begin{array}{l}\text { Energy efficiency standards } \\
\text { for renovation }\end{array}$ & $\begin{array}{l}\text { Directive on the energy } \\
\text { performance of buildings }\end{array}$ & $\begin{array}{l}\text { National building code } \\
\text { requirements, } 2015 \text { or } \\
\text { planned tightening as far as } \\
\text { data available }\end{array}$ \\
\hline 3 & $\begin{array}{l}\text { Energy efficiency standards } \\
\text { new buildings }\end{array}$ & $\begin{array}{l}\text { Directive on the energy } \\
\text { performance of buildings }\end{array}$ & $\begin{array}{l}\text { National implementation of } \\
\text { nearly zero-energy building } \\
\text { (NZEB) standards after } 2018 \\
\text { (for public buildings) and } \\
2020 \text { (for all buildings). }\end{array}$ \\
\hline 4 & RES obligation & Renewable energy directive & $\begin{array}{l}\text { Current implementation in } \\
\text { Member States (only for new } \\
\text { buildings in few countries), } \\
\text { increased share of biofuels } \\
\text { for all transport modes, } \\
\text { reduced biofuels taxation for } \\
\text { transport use }\end{array}$ \\
\hline 5 & Energy labeling & Energy labeling directive & $\begin{array}{l}\text { Mandatory for new devices } \\
\text { for appliances already } \\
\text { included /initiated in } 2016\end{array}$ \\
\hline 6 & EU Emission Allowances & Emission Trading Scheme & $\begin{array}{l}\mathrm{CO}_{2} \text { price: increase to } \\
90 \mathrm{EUR} / \mathrm{t}_{\mathrm{CO} 2} \text { in } 2050 \text { (e.g., } \\
\text { from EU Reference Scenario } \\
2016 \text { or model result) } \\
\text { Transport sector: increase of } \\
\text { cost (e.g., air mode) }\end{array}$ \\
\hline 7 & Energy and $\mathrm{CO}_{2}$ taxation & Energy Taxation Directive & $\begin{array}{l}\text { Taxes varying by fuel and } \\
\text { sector and by country (e.g., } \\
\text { German RES levy) } \\
\end{array}$ \\
\hline 8 & Energy saving obligation & Energy Efficiency Directive & $\begin{array}{l}\text { Current implementation in } \\
\text { Member States } 1.0-1.5 \% \text { p.a. }\end{array}$ \\
\hline 9 & Fuel Quality & Fuel Quality Directive & $\mathrm{CO}_{2}$ emission factor for fuels \\
\hline 10 & $\begin{array}{l}\text { Clean and Energy Efficient } \\
\text { Road Transport Vehicles }\end{array}$ & $\begin{array}{l}\text { Directive on the Promotion } \\
\text { of Clean and Energy } \\
\text { Efficient Road Transport } \\
\text { Vehicles }\end{array}$ & $\begin{array}{l}\text { Renewal of the road vehicle } \\
\text { fleet }\end{array}$ \\
\hline 11 & $\begin{array}{l}\mathrm{CO}_{2} \text { standard for new cars } \\
\text { and vans }\end{array}$ & $\begin{array}{l}\text { EU regulation on } \mathrm{CO}_{2} \\
\text { emission from new cars and } \\
\text { vans }\end{array}$ & $\begin{array}{l}\text { Renewal and technology of } \\
\text { cars and vans vehicle fleet }\end{array}$ \\
\hline
\end{tabular}


Table 2.2 (continued)

\begin{tabular}{c|l|l|l}
\hline $\mathrm{N}^{\circ}$ & Measures/Regulations & Legislative & Implementation \\
\hline 12 & Aviation policies & Single European Sky II & $\begin{array}{l}\text { Air non fuel cost, air access } \\
\text { time to airport, air fuel } \\
\text { consumption }\end{array}$ \\
\hline 13 & $\begin{array}{l}\text { Aviation policies on } \\
\text { emissions }\end{array}$ & $\begin{array}{l}\text { ICAO Chapters 3 } \\
\text { (reduction of noise at } \\
\text { source emissions) }\end{array}$ & Air emission factors \\
\hline 14 & Maritime energy efficiency & $\begin{array}{l}\text { IMO Energy Efficiency } \\
\text { Design Index (EEDI) }\end{array}$ & $\begin{array}{l}\text { Reduced ship fuel } \\
\text { consumption factor }\end{array}$ \\
\hline
\end{tabular}

${ }^{a}$ Cut-off date: end of 2015, MEPS—Minimal Energy Performance Standards, ICAO—International Civil Aviation Organization, IMO_-International Maritime Organization

technologies/modes, and to alternative fuels as they summarized in Table 2.3 for the industry and tertiary and residential buildings and appliances as well in Table 2.4 for the transport sector.

\subsubsection{Centralized High-RES Scenario}

\subsubsection{Scenario Framework of a 'Centralized World'}

The centralized High-RES scenario describes a world, in which the electricity market will be dominated by large scale offshore and onshore wind power plants at prime locations. To realize the advantages of such system, i.e., rather low generation costs and making use of deviating loads between North and South Europe, the required grid infrastructure needs to be integrated. Despite the high share of RES, the scenario would allow for some large scale conventional, low-carbon emitting power plants and nuclear power plants.

The heat production for residential and office buildings is centralized in the cities, equipped with large scale thermal storage charged with power-to-heat technologies, such as heat pumps and electric boilers (cf. Table 2.3). Hydrogen is produced in larger plants with distribution by trailers and pipelines. This leads to higher perceived reliability concerning hydrogen infrastructure deployment and stability of hydrogen prices compared to decentralized world due to less actors and need for coordination combined with clear decisions and communication.

Economies of scale will promote larger capacities of conversion technologies (as long as policy interventions will not encourage investment in small scale technologies), resulting in a more centralized world. But the costs of transporting energy will influence the degree of centralization, i.e., high transport costs could hinder the establishment of a centralized world. Having said that, a 'centralized world' can be characterized by a more market-oriented paradigm, assuming in the scenario that economies of scale will dominate transport costs. The selection of the energy 
Table 2.3 Key assumptions and differentiating factors for the High-RES industry, tertiary and residential scenarios. Table according to Zöphel et al. (2019)

\begin{tabular}{|c|c|c|}
\hline Clusters of mitigation options & Mod-RES & High-RES \\
\hline \multicolumn{3}{|l|}{ Industry } \\
\hline $\begin{array}{l}\text { Incremental efficiency } \\
\text { improvement }\end{array}$ & $\begin{array}{l}\text { Energy efficiency progress } \\
\text { according to current policy } \\
\text { framework and historical } \\
\text { trends. }\end{array}$ & $\begin{array}{l}\text { Faster diffusion of incremental } \\
\text { process improvements } \\
(\text { BAT \& INNOV } \geq \text { TRL 5) }\end{array}$ \\
\hline $\begin{array}{l}\text { Fundamental processes } \\
\text { improvement }\end{array}$ & - & $\begin{array}{l}\text { Radical process changes } \\
\text { (INNOV } \geq \text { TRL 5) }\end{array}$ \\
\hline $\begin{array}{l}\text { Fuel switching to RES, } \\
\text { decarbonized electricity and } \\
\text { hydrogen }\end{array}$ & $\begin{array}{l}\text { Fuel switching driven by } \\
\text { energy prices and assumed } \\
\mathrm{CO}_{2} \text { price increase }\end{array}$ & $\begin{array}{l}\text { High financial support for } \\
\text { RES technologies (biomass, } \\
\text { power-to-heat, power-to-gas) } \\
\text { Additional financial support } \\
\text { for the use of district heating } \\
\text { in the centralized scenario. } \\
\text { Radical changes in industrial } \\
\text { process technologies drive fuel } \\
\text { switch (e.g., switch to } \\
\text { hydrogen) }\end{array}$ \\
\hline Recycling and re-use & $\begin{array}{l}\text { Slow increase in recycling } \\
\text { rates based on historical trends }\end{array}$ & $\begin{array}{l}\text { Stronger switch to secondary } \\
\text { production }\end{array}$ \\
\hline $\begin{array}{l}\text { Material efficiency and } \\
\text { substitution }\end{array}$ & Based on historic trends & $\begin{array}{l}\text { Increase in material efficiency } \\
\text { and substitution }\end{array}$ \\
\hline \multicolumn{3}{|c|}{ Tertiary and residential buildings $\&$ appliances } \\
\hline $\begin{array}{l}\text { Energy efficiency of } \\
\text { residential \& tertiary } \\
\text { buildings } \\
\text { Building standards for new } \\
\text { and renovated buildings, } \\
\text { compliance }\end{array}$ & $\begin{array}{l}\text { Current national } \\
\text { implementation of regulations } \\
\text { (nearly zero-energy buildings } \\
\text { from 2021), high compliance }\end{array}$ & $\begin{array}{l}\text { Higher building standards for } \\
\text { renovation, very high } \\
\text { compliance, financial } \\
\text { incentives }\end{array}$ \\
\hline Renovation rate & Remains at the current status & $\begin{array}{l}\text { Increases by } 70 \% \text { (up to } 2 \% \text { ) } \\
\text { until } 2050\end{array}$ \\
\hline $\begin{array}{l}\text { Heating supply in buildings } \\
\text { Technology choice, lifetime }\end{array}$ & $\begin{array}{l}\text { Implemented national } \\
\text { incentives and subsidies stay in } \\
\text { force, no additional fuel tax } \\
\text { Average lifetime } 20-30 \text { years }\end{array}$ & $\begin{array}{l}\text { Financial incentives for heat } \\
\text { pump investments, financial } \\
\text { revenue for heat pump } \\
\text { flexibility, expansion of } \\
\text { district heating networks, ban } \\
\text { of oil boilers from 2030, } \\
\text { additional tax on gas and oil } \\
\text { Average lifetime } 20 \text { years }\end{array}$ \\
\hline $\begin{array}{l}\text { Energy efficiency progress } \\
\text { of appliances }\end{array}$ & $\begin{array}{l}\text { Ecodesign directive in today's } \\
\text { implementation and further } \\
\text { announced reinforcement }\end{array}$ & $\begin{array}{l}\text { Ecodesign directive in today's } \\
\text { implementation and further } \\
\text { announced reinforcement, plus } \\
\text { new efficiency classes and } \\
\text { more products from } 2025\end{array}$ \\
\hline
\end{tabular}

\footnotetext{
${ }^{1}$ BAT—best available technology, INNOV—innovation, TRL—technology readiness level
} 
Table 2.4 Key assumptions and differentiating factors for both High-RES transport scenarios. Table according to Zöphel et al. (2019)

\begin{tabular}{|c|c|c|c|c|}
\hline \multicolumn{3}{|c|}{ Strategies } & \multicolumn{2}{|l|}{ High-RES } \\
\hline$(1)$ & $(2)$ & (3) & Decentralized & Centralized \\
\hline \multirow[t]{4}{*}{$X$} & & $\mathrm{X}$ & \multicolumn{2}{|c|}{$\begin{array}{l}\text { Road infrastructure pricing based on emissions, diffusion of Collaborative } \\
\text { Intelligent Transport Systems applications, urban policies to promote } \\
\text { sustainable mobility, measures promoting efficiency improvements, and } \\
\text { multimodality }\end{array}$} \\
\hline & $X$ & & \multicolumn{2}{|c|}{$\begin{array}{l}\text { Increased fuel tax for conventional fuels, reduced fuel tax for electricity, } \\
\text { hydrogen, and biofuels }\end{array}$} \\
\hline & $X$ & $X$ & \multicolumn{2}{|c|}{$\begin{array}{l}\text { Filling and charging station deployment is further expanded, fast charging } \\
\text { increases acceptance of BEV and enables driving longer distances }\end{array}$} \\
\hline & & $\mathrm{X}$ & \multicolumn{2}{|c|}{$\begin{array}{l}\text { More ambitious } \mathrm{CO}_{2} \text { standards for new cars and light duty vehicles and } \\
\text { extension of standards to buses and trucks }\end{array}$} \\
\hline \multirow[t]{6}{*}{$\mathrm{X}$} & & $\mathrm{X}$ & $\begin{array}{l}\text { Higher acceptance of multi-modal } \\
\text { transport increases the use of car } \\
\text { sharing and leads to more walking } \\
\text { and cycling. Car sharing fleets have a } \\
\text { higher share of electric vehicles. }\end{array}$ & \\
\hline & & $\mathrm{X}$ & $\begin{array}{l}\text { Strongly increasing number of } \\
\text { households with rooftop PV } \\
\text { accelerates the diffusion of electric } \\
\text { vehicles due to economic advantages } \\
\text { by own electricity production and } \\
\text { higher technical affinity }\end{array}$ & \\
\hline & & $X$ & $\begin{array}{l}\text { Spillovers from stationary battery } \\
\text { storages could accelerate the } \\
\text { reduction of battery prices }\end{array}$ & \\
\hline & $X$ & $X$ & \multicolumn{2}{|c|}{$\begin{array}{l}\text { FCEV as zero-emission technology choice for intermediate and long-distance } \\
\text { trucks, advanced research and innovation for fuel cell technology and decision } \\
\text { on deployment of hydrogen refueling infrastructure in all EU-28 countries }\end{array}$} \\
\hline & $X$ & & $\begin{array}{l}\text { Hydrogen production directly at the } \\
\text { filling stations }\end{array}$ & $\begin{array}{l}\text { Hydrogen production in larger plants } \\
\text { with distribution by trailers and } \\
\text { pipelines }\end{array}$ \\
\hline & $X$ & $\mathrm{X}$ & & $\begin{array}{l}\text { Higher perceived reliability concerning } \\
\text { hydrogen infrastructure deployment } \\
\text { and stability of hydrogen prices } \\
\text { compared to decentralized world due } \\
\text { to less actors and need for coordination } \\
\text { combined with clear decisions and } \\
\text { communication }\end{array}$ \\
\hline
\end{tabular}


Table 2.4 (continued)

\begin{tabular}{l|l|l|l|l}
\hline \multicolumn{3}{l|}{ Strategies } & \multicolumn{3}{l}{ High-RES } \\
\hline$(1)$ & $(2)$ & $(3)$ & Decentralized & Centralized \\
\hline & & $\mathrm{X}$ & $\begin{array}{l}\text { Phase-out of pure ICE vehicles for new urban buses with completion in } 2035 \\
\text { and for new cars and light duty vehicles in 2040 }\end{array}$ \\
\hline
\end{tabular}

*Impact of the assumptions related to the three main European strategies for the transport sector

(1) Increasing the efficiency of the transport system

(2) Speeding up the deployment of low-emission alternative energy

(3) Moving toward zero-emission vehicles

technologies as well as flexibility options will follow more profit-oriented rules. Current regulations, which support local, non-commercialized energy provision, are not extended. A market-oriented paradigm means also a rather traditional organization of energy markets, i.e., the classical dichotomy of supply and demand will apply; prosumers or non-profit-oriented energy association will not experience a noteworthy share at the electricity market.

A pre-condition for this is a general acceptance of the required infrastructures, e.g., of HVDC lines, or intervention into nature, e.g., to establish wind onshore plants on fallow land, in affected regions. This acceptance could be either the result of appropriate incentive systems, like the possibility to buy shares of the network operators at preferential conditions or the common understanding that the economic advantages of such centralized system outweigh the environmental disadvantages.

The establishment of such an energy system requires corresponding measures by the national governments and the European Commission, following a centralized policy scheme, e.g., directing expansion plans. Limiting appeals by citizen to speed up investment in the grid could be part of such a policy.

\subsubsection{Flexibility Options in a 'Centralized World'}

A characteristic of the 'centralized world' is an intra-European trade of electricity, i.e., excess demand or excess supply in one region can be mostly, if not completely, buffered by other regions. Additionally, respective large storage systems are available for balancing the grid system. More centralized information availability on status and condition of large scale power plants allows for better forecasting of available renewable generation (day ahead). Based on the available and precise information on generation capacity online at every time interval, the need for demand side flexibility is limited. Other central options, e.g., flexible power plants or the use of backup capacity from large storage, would be more cost competitive to balance electricity supply and demand compared to decentralized smaller scale demand side measures which would need to be aggregated to support grid stability.

Therefore, in the tertiary sector, only very limited appliances and technologies (energy services) with a large electricity demand would be effectively used for demand side measures such as cold storage houses, large night storage heater or 
heat pumps, and large ventilation, and air-conditioning systems. As of today, these large energy services make up only a small share of the electricity demand from the tertiary sector in Europe, whereas only a fraction of this demand is theoretical available for demand side management (DSM) measures. In a 'centralized world,' this very limited flexibility potential would be considered as stable. Depending on the country regulation for participation in the balancing market, this DSM potential is already tapped as of today. These DSM options would be centrally controlled and marketed on balancing markets where grid operators are solely responsible for requesting the needed DSM capacities.

Transport and power-to-x technologies could be additional flexibility options. Whether power-to-x technologies will play an important role, depends on the abundance of off-peak electricity, next to technical restrictions, like flexibility of downstream technologies and low energy efficiency in case of re-electrification. The revenues from selling off-peak stored electricity have to match the high annualized investment and operating costs, at least. The abundance of off-peak electricity in a 'centralized world' may be low, if the abovementioned flexibility options will be successfully applied. Flexibility options within the mobility sectors will mainly occur with the diffusion of electric mobility.

\subsubsection{Decentralized High-RES Scenario}

\subsubsection{Scenario Framework of a 'Decentralized World'}

In contrast to the 'centralized world,' the decentralized High-RES scenario characterizes an electricity market which will be dominated by rooftop PV plants and wind onshore power plants at all possible locations, amended by further local based energy technologies, like small scale biomass power plants. A consequence should be a diminishing relevance of intra-European trade of electricity. Large conventional power plants will be rather negligible. The residential heat production is backed by solar systems and small scale storage systems. Through the following three factors a faster diffusion of electric vehicles is expected in the High-RES decentralized scenario compared to the centralized scenario. First, the strongly increasing number of households with rooftop PV accelerates the diffusion of electric vehicles. Second, battery prices decline faster due to additional learning curve effects based on spillovers from stationary battery storages leading to lower selling prices of BEVs and PHEVs. Third, people are more familiar with DSM and digitalized monitoring and control, and thus a higher acceptance of multi-modal transport is assumed including more use of car sharing as well as more walking and cycling. This behavior change increases the number of vehicles in car sharing fleets that tend to have a higher share of electric vehicles. Furthermore, the hydrogen production for the demand side is decentralized and directly located at the filling stations and industrial production sites. 
A 'decentralized world' implies that non-efficiency oriented factors are gaining influence in the shaping of the future energy system. A main driving force for many advocates is the conviction that only grassroot movements could secure the energy transition toward RES and would impede a non-sustainable energy system (cf. Viardot et al. 2013). The local or regional energy systems (including local infrastructure) have to be owned and controlled by local groups or local residents to secure among other a fairer distribution of wealth by breaking up the market power of large utilities. However, the REFLEX decentralized High-RES scenario will allow for profit-oriented companies as market participants. Although in such a world, profitorientation will not be the dominant motivation for providing energy, the operator will organize the energy system still cost-efficiently. A 'decentralized world' could also be a consequence of a deep-rooted opposition in affected regions against new HV or HVDC lines, which cannot be overcome by policies. A pre-condition for a 'decentralized world' is a general acceptance of relevant power and heat energy conversion technologies either in the neighborhood or in the buildings. This could mean to some extent intervention into nature, e.g., to establish decentralized wind power plants. This acceptance could be either the results of appropriate incentive systems, like the possibility to participate at the profits of energy sale, or by reduced tariffs. The establishment of such an energy system requires corresponding measures by the national governments and the European Commission. But in contrast to the 'centralized world,' these measures will set only a broad legal and economic frame for establishing local groups, like local energy associations and has to be amended by regional or local directives and pushed by local groups. The transformation is more a bottom-up process.

A pre-condition for both scenarios is the switch of the current energy system to smart(er) grids, smart metering, and smart appliances and thus, acceptance by the user for those technologies (cf. Verbong et al. 2013). The demands for smart systems will differ between both scenario worlds, since the requirements regarding the control systems and the combination of flexibility options are influenced by the '(de-)centralization' grade of the energy system.

\subsubsection{Flexibility Options in a 'Decentralized World'}

In the 'de-centralized world,' the generation capacities are spatially more evenly distributed as well as the storage capacities. Therefore, the grid infrastructure for large distance transmission is also limited. The probability for precise generation forecasting decreases due to the high number of participants and the high uncertainty on effective available renewable generation (downtime of plants). All together these are arguments for an increasing need for demand side flexibility. In addition to the already mentioned energy services for DSM in the 'centralized world,' additional technologies would be integrated like air-conditioning and ventilation systems, freezers and refrigerators, other white appliances, small night storage heater and heat pumps, and other tertiary sector processes. By including these technologies, the theoretical potential for DSM increases. To which extent is investigated in the 
REFLEX project and thus, is rather a model results than a scenario assumption (cf. Part III). The abovementioned DSM potential focuses mainly on households and tertiary sector. The DSM potential of industry under such scenario is unclear. The potential is determined among others by production process (batch vs. continuous), produced product (storable over hours vs. storable less than an hour vs. non-storable), company-internal workflows (flexible working hours vs. non-flexible ones), provision of energy (internal vs. external and batch vs. continuous) and organization of supply and demand chains (just-in-time vs. batch). In the 'decentralized world,' a strong ability of industrial process flexibility is assumed, however, limited by thermodynamic and economic constraints. The latter means, that technical flexibility potentials are only exploited as long as these are not contradicting the profit-orientation of industry companies. To which extent the flexibility potentials are present needs to be investigated and is therefore a project result.

The relevance of flexibility options within the mobility sectors mainly depends on the market penetration of electric mobility as well as mobility services and autonomous driving cars in car sharing fleets. On the one hand, fleet operators can shift charging processes during the day taking the passenger transport demand situation into account. On the other hand, the availability of better infrastructure allows also private users to adapt their preferences to a different daily charging profile. Compared to today's charging strategies (mostly at home and in the evening), electric cars can be charged during off-peak hours.

As mentioned above, the abundance of available off-peak electricity and some technical impediments could reduce the role of power-to-x technologies as a flexibility option. Furthermore, as long as no small scale applications of power-to-x technologies are developed, the demand for electricity by the technology could outmatch the available off-peak electricity within a region.

\subsection{Conclusions}

According to the political aim of most member states of the EU and the one of the European Commission, the future energy system will be dominated by a high share of RES, of which wind and solar energy are characterized by high intermittency. To manage this system, economic flexibility potentials have to be identified and quantified. Within REFLEX the analysis of the flexibility potential is based on two main scenarios: Mod-RES and High-RES (decentralized/centralized). The first consideration shows a high interrelationship between the design of the energy system and the flexibility potentials. However, a further elaboration of the interdependencies is necessary. Considering the energy system as a socio-technical system, both discussed scenarios are based on different societal demands regarding the underlying aims of the transformation process, i.e., whether 'only' climate change shall be taken into account or whether the transformation is also used to realize a 'more democratic' 
provision of energy. Both scenarios characterize a possible pathway for transformation with highlighting two probable characteristics under the assumption that the overall framework will not be altered by reality until 2050 .

\section{References}

Bernstein L, Bosch P, Canziani O, Chen Z, Christ R, Davidson O et al (2008) Climate change 2007: synthesis report: an assessment of the intergovernmental panel on climate change

Capros P, De Vita A, Tasios N, Siskos P, Kannavou M, Petropoulos A, Evangelopoulou S, Zampara M, Papadopoulos D, Paroussos L, Fragiadakis K, Tsani S, Fragkos P, Kouvaritakis N, HöglundIsaksson L, Winiwarter W, Purohit P, Gomez-Sanabria A, Frank S, Forsell N, Gusti M, Havlík P, Oberstei M, Witzke HP, Kesting M (2016) EU reference scenario 2016-energy, transport and GHG emissions-trends to 2050. European Commission, Brussels

COM (2011/0112) Communication from the commission to the European parliament, the Council, the European economic and social committee and the committee of the regions: a roadmap for moving to a competitive low-carbon economy in 2050

EC (2020) A European green deal—striving to be the first climate-neutral continent. https://ec.eur opa.eu/info/strategy/priorities-2019-2024/european-green-deal_en. Accessed on 28 Sept 2020)

Fuss M, Brown N, Ekener E, Herbst A (2018) D1.3 updated modelling parameters considering insights from life cycle approaches. REFLEX project report

Herbst A, Michaelis J, Brown N, Jakob M, Martino A (2016) Qualitative description of the scenario storylines. Update. REFLEX project report

Pachauri RK, Allen MR, Barros VR, Broome J, Cramer W, Christ R, Dubash NK (2014). Climate change 2014: synthesis report. Contribution of working groups I, II and III to the fifth assessment report of the intergovernmental panel on climate change. IPCC 151

Poganietz WR, Kühn A, Reiter U, Fermi F (2017) Flexibility options in the context of future energy systems-some scenario-based reflections. REFLEX policy brief

UNEP (2007) Global Environmental Outlook. GEO-4. Environment for development. United Nations Environment Programme, Nairobi, Kenya

UNEP (2012) Global Environmental Outlook. GEO-5. Environment for the future we want. United Nations Environment Programme

van Vuuren DP, Kok MTJ, Girod B et al (2012) Scenarios in global environmental assessments: key characteristics and lessons for future use. Glob Environ Chang 22(4):884-895

Verbong GPJ, Loorbach D (eds) (2012) Governing the energy transition: reality, illusion or necessity? Routledge studies in sustainability transitions, vol 4. Routledge Taylor \& Francis Group, New York

Verbong PJ, Beemsterber S, Sengers F (2013) Smart grids or smart users? Involving users in developing a low carbon electricity economy. Energy Policy 52:117-125. https://doi.org/10.1016/ j.enpol.2012.05.003

Viardot E, Wierenga T, Friedrich B (2013). The role of cooperatives in overcoming the barriers to adoption of renewable energy. Energy Policy 63:756-764. https://doi.org/10.1016/j.enpol.2013. 08.034

Watson RT, Albritton DL (2001) Climate change 2001: synthesis report: third assessment report of the intergovernmental panel on climate change. Cambridge University Press

Zöphel C, Schreiber S, Herbst A et al (2019) Report on cost optimal energy technology portfolios for system flexibility in the sectors heat, electricity and mobility. REFLEX project report 


\section{Legislative Directives and Regulations}

Directive 2009/125/EC of the European Parliament and of the Council of 21 October 2009 establishing a framework for the setting of ecodesign requirements for energy-related products

Directive 2009/28/EG of the European Parliament and the Council of 23 April 2009 on the promotion of the use of energy from renewable sources and amending and subsequently repealing Directives 2001/77/EC and 2003/30/EC. OJEU L 140/16. 5 June 2009

Directive 2009/30/EC of the European Parliament and of the Council of 23 April 2009 amending Directive 98/70/EC as regards the specification of petrol, diesel and gas-oil and introducing a mechanism to monitor and reduce greenhouse gas emissions and amending Council Directive 1999/32/EC as regards the specification of fuel used by inland waterway vessels and repealing Directive 93/12/EEC

Directive 2010/31/EU of the European Parliament and the Council of 19 May 2010 on the energy performance of buildings (recast). OJEU L 153/13 18 June 2010

Directive 2012/27/EU of the European Parliament and the Council of 25 October 2012 on energy efficiency, amending Directives 2009/125/EC and 2010/30/EU and repealing Directives 2004/8/EC and 2006/32/EC. OJEU L 315/1. 14 November 2012

Regulation (EU) No 253/2014 of the European Parliament and of the Council of 26 February 2014 amending Regulation (EU) No 510/2011 to define the modalities for reaching the 2020 target to reduce $\mathrm{CO}_{2}$ emissions from new light commercial vehicles Text with EEA relevance

Regulation (EU) No 333/2014 of the European Parliament and of the Council of 11 March 2014 amending Regulation (EC) No 443/2009 to define the modalities for reaching the 2020 target to reduce $\mathrm{CO}_{2}$ emissions from new passenger cars

Open Access This chapter is licensed under the terms of the Creative Commons Attribution 4.0 International License (http://creativecommons.org/licenses/by/4.0/), which permits use, sharing, adaptation, distribution and reproduction in any medium or format, as long as you give appropriate credit to the original author(s) and the source, provide a link to the Creative Commons license and indicate if changes were made.

The images or other third party material in this chapter are included in the chapter's Creative Commons license, unless indicated otherwise in a credit line to the material. If material is not included in the chapter's Creative Commons license and your intended use is not permitted by statutory regulation or exceeds the permitted use, you will need to obtain permission directly from the copyright holder.

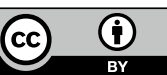

